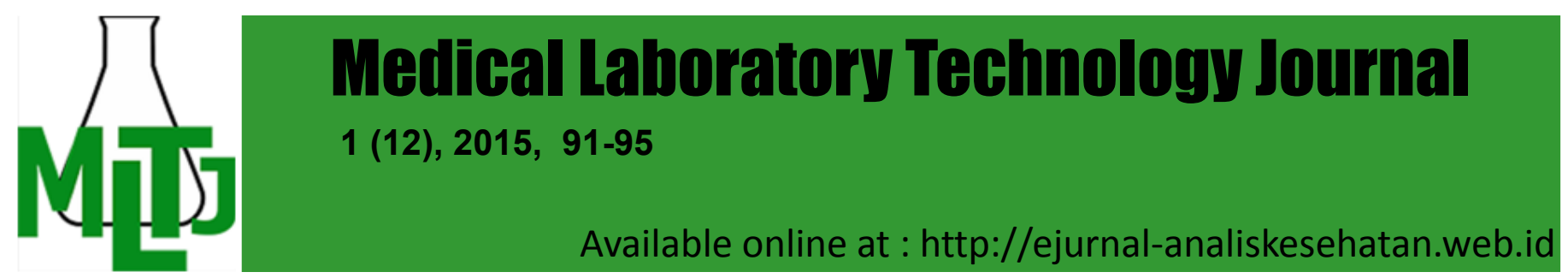

\title{
PERBEDAAN JUMLAH TROMBOSIT PADA DARAH EDTA YANG SEGERA DIPERIKSA DAN PENUNDAAN SELAMA 1 JAM DI LABORATORIUM RSJ GRHASIA YOGYAKARTA
}

\author{
Sujud, Ratih Hardiasari, Anik Nuryati \\ Jurusan Analis Kesehatan Kemenkes Yogyakarta \\ Ngadinegaran MJ III/62 Yogyakarta 55143, 0274-374200 \\ e-mail: Sujud70@yahoo.com.id
}

\begin{abstract}
Pre-analytical phases is a very important stage and need to be considered properly. Pre-analytical phases of which is the process of blood sampling, sample delivery, the inclusion of the type of inspection, sample preparation and selection tools. A fact which still often the case that their neglect by nurses or laboratory personnel in taking and processing the blood samples. Blood samples for examination platelet counts as much as possible is done properly and the sample must be examined in less than 1 hour after taking blood. Delays checks can cause a decrease in platelet count. Delays often occur for over an hour due to the shipment of samples from wards that are not immediately performed or work shift lab personnel. The aim of research to determine the difference in the number of platelets in the blood EDTA is immediately checked and a delay of 1 hour by using KX-21 Hematology analyzer. Experimental study design with preand post-test study without control. The study was conducted at the Laboratory of RSJ Grhasia Yogyakarta, with the object of research is venous blood from patients RSJ Grhasia between the ages of 20-50 years of both men - men and women. Data were analyzed parametric statistical tests Paired samples t-test. The results of significant research value of the results of parametric statistical tests Paired samples t-test was 0,000 (sig <0.05). There is a difference between the number of blood platelets EDTA is immediately checked and a delay of 1 hour.
\end{abstract}

Keywords: platelet count, blood EDTA, time delays.

Abstrak: Tahapan Pra-analitik merupakan tahapan yang sangat penting dan perlu diperhatikan dengan baik. Tahapan pra-analitik diantaranya adalah proses pengambilan darah, pengiriman sampel, pencatuman jenis pemeriksaan, persiapan sampel dan pemilihan alat. Fakta yang masih sering terjadi yaitu adanya pengabaian oleh perawat atau tenaga laboratorium dalam mengambil dan mengolah sampel darah. Pengambilan sampel darah untuk pemeriksaan jumlah trombosit sebisa mungkin dilakukan dengan benar dan sampel harus segera diperiksa dalam waktu kurang dari 1 jam setelah pengambilan darah. Penundaan pemeriksaan dapat menyebabkan penurunan jumlah trombosit. Penundaan sering terjadi selama lebih satu jam dikarenakan pengiriman sampel dari bangsal yang tidak segera dilakukan atau pergantian shift kerja petugas laboratorium. Tujuan penelitian untuk mengetahui perbedaan jumlah trombosit pada darah EDTA yang segera diperiksa dan penundaan selama 1 jam dengan menggunakan alat Hematology Analizer KX-21. Penelitian eksperimen dengan desain penelitian pre and post test without control. Penelitian dilakukan di Laboratorium RSJ Grhasia Yogyakarta, dengan obyek penelitian adalah darah vena dari pasien RSJ Grhasia dengan umur antara 20 - 50 tahun baik laki - laki maupun perempuan. Data dianalisa uji statistik parametrik Paired Sampel $t$-Test. Hasil penelitian Nilai signifikan dari hasil uji statistik parametrik dengan Paired Sampel t-Test adalah 0,000 (sig $<0,05)$. Ada perbedaan antara jumlah trombosit darah EDTA yang segera diperiksa dan penundaan selama 1 jam.

Kata Kunci :Jumlah trombosit, darah EDTA, waktu penundaan. 


\section{PENDAHULUAN}

Pemeriksaan

Hematologi

yang

termasuk dalam Faal Hemostasis yaitu Hitung Trombosit, Clothing Time, Blooding Time, Plasma Prothrombine Time, Activated Partial Thromboplastin Time. Salah satu pemeriksaan faal hemostasis yang penting adalah hitung trombosit. Pemeriksaan ini bertujuan untuk menghitung jumlah trombosit yang ada pada tiap $1 \mathrm{ml}$ darah. Penurunan jumlah trombosit yang signifikan tentu akan berpengaruh dalam proses pembekuan darah. Sampel yang akan digunakan dalam pemeriksaan Hitung trombosit adalah darah vena dengan antikoagulan EDTA (Ethylendiamine Tetyraacetic Acid) yang berfungsi untuk mencegah penggumpalan trombosit.Karena sesuatu hal, kadang pemeriksaan ini harus tertunda selama beberapa waktu. Meskipun demikian dianjurkan agar semua pemeriksaan hematologi dikerjakan paling lama dua jam setelah pengambilan sampel, karena dikawatirkan akan terjadi perubahan sifat, morfologi maupun jumlah sel yang ada.

Hitung trombosit merupakan salah satu pemeriksaan yang sangat penting untuk berbagai kasus baik yang menyangkut hemostasis maupun kasus lain yang meliputi penegakan diagnosis, penilaian hasil terapi atau perjalanan suatu penyakit, penentuan prognosis dan penilaian berat tidaknya suatu penyakit . Hal tersebut dapat terjadi jika dalam mengerjakan sampel harus memperhatikan hal - hal yang dimulai dari persiapan alat, persiapan tempat pengambilan, cara pengambilan sampel, volume sampel, tindakan sesudah pengambilan sampel dan penanganan sampel yang telah diambil.

Jumlah trombosit di dalam tubuh sangat dipengaruhi oleh berbagai faktor. Secara garis besar nilai normal (rentang normal) jumlah trombosit antara 110 ribu sampai 450 ribu per $\mathrm{mm}^{3}$ darah .

$$
\text { Trombosit dihitung dengan }
$$
menggunakan mesin hitung elektrik sehingga banyak trombosit yang dapat dihitung. Teknik ini dapat menimbulkan kesalahan kalau jumlah lekosit melebihi $100.000 / \mathrm{mm}^{3}$, bila ada fragmentasi eritrosit yang berat, bila larutan pengencer tidak bebas partikel, bila sampel darah dibiarkan bebas terlalu lama sebelum dilakukan pemeriksaan atau bila trombosit melekat satu dengan yang lain.

Pengambilan sampel darah untuk pemeriksaan jumlah trombosit diusahakan dilakukan dengan benar dan harus segera diperiksa dalam waktu kurang dari 1 jam setelah pengambilan darah. Penundaan pemeriksaan dapat menyebabkan penurunan jumlah trombosit, tetapi jika terdapat suatu sebab pemeriksaan untuk tidak bisa dilakukan segera maka sampel boleh disimpan pada suhu $4-8^{0} \mathrm{C}$.

Kondisi yang terjadi di Rumah Sakit Jiwa Grhasia pada prakteknya terutama yang sering terjadi pada rawap inap, sering terdapat penundaan pemeriksaan sampel, sering terjadi penundaan pemeriksaan sampel darah selama lebih 1 jam. Pemeriksaan sampel darah tersebut tertunda sampai melebihi waktu yang seharusnya dianjurkan dalam pemeriksaan sampel darah dikarenakan pengiriman sampel dari bangsal yang tidak segera dilakukan atau petugas laboratorium dalam pengambilan sampel darah tidak segera diperiksa di laboratorium dikarenakan pergantian shif jaga atau petugas laboratorium dalam melakukan pengambilan sampel terlalu lama di bangsal dikarenakan pasien yang mau diambil darahnya terlalu banyak. Peneliti berdasarkan hal tersebut, bermaksud melakukan pemeriksaan Hitung Jumlah Trombosit pada darah EDTA yang segera diperiksa dan penundaan selama satu jam.

\section{BAHAN DAN METODE}

Jenis penelitian ini adalah penelitian eksperimen yaitu percobaan yang berupa perlakuan atau intervensi terhadap suatu variabel (Notoatmodjo,2005). Eksperimen yang dilakukan yaitu dengan memeriksa jumlah trombosit pada sampel darah EDTA dengan menggunakan metode otomatis memakai alat Sysmex yang langsung diperiksa. Selain itu juga dilakukan pemeriksaan jumlah hitung vena mediana cubitti dengan obyek penelitian berasal dari pasien Rumah Sakit Jiwa Grhasia Yogyakarta yang sehat jasmani. Riwayat penyakit diketahui dengan melakukan wawancara terhadap keluarga pasien dan Buku Medical Record sebelum melakukan penelitian. Jumlah sampel yang digunakan 
sebanyak 30 sampel dengan menggunakan antikoagulan trombosit sampel darah EDTA dengan penundaan selama satu jam. Desain penelitiannya adalah pre and post without control. Jumlah trombosit dengan sampel darah EDTA langsung diperiksa adalah pre test, sedangkan jumlah trombosit setelah pendiaman satu jam adalah post test .

Subyek penelitian ini adalah darah vena dari pasien RSJ Grhasia DIY sebanyak 30 sampel baik laki - laki maupun perempuan dengan umur sekitar 20 - 50 tahun, tidak ada riwayat penyakit yang berhubungan dengan kelainan darah terutama penyakit yang berkaitan dengan proses hemostasis. Riwayat penyakit diketahui dari dengan cara melihat buku Medical Record atau buku Daftar Isian
Riwayat Pasien.

Jumlah trombosit yang terdapat pada tabung vacuntainer sampel darah EDTA yang akan diperiksa dengan alat Hematology Analizer KX 21

\section{HASIL DAN PEMBAHASAN}

Data penelitian ini diperoleh dari hasil penelitian terhadap jumlah trombosit yang dilakukan pada bulan Juli 2014. Sampel darah yang digunakan diambil dari EDTA. Masingmasing sampel dilakukan pemeriksaan jumlah trombosit dengan menggunakan sysmex $\mathrm{KX}$ 21 tanpa pendiaman (0 jam) dan pemeriksaan jumlah trombosit setelah pendiaman selama satu jam. Data yang diperoleh kemudian dilakukan uji deskriptif dan statistik.

\section{Analisis Deskriptif}

Tabel 1. Uji Deskriptif Rata-Rata Jumlah Trombosit

\begin{tabular}{lccccc}
\hline & Jumlah & Rerata & $\begin{array}{c}\text { Nilai Teren- } \\
\text { dah }\end{array}$ & $\begin{array}{c}\text { Nilai } \\
\text { Tertinggi }\end{array}$ & $\begin{array}{c}\text { Penurunan } \\
(\%)\end{array}$ \\
\hline $\begin{array}{l}\text { Tanpa pendiaman }(0 \\
\text { jam }) \\
\text { dalam }\left(\mathrm{sel} / \mathrm{mm}^{3}\right)\end{array}$ & 30 & 285.333 & 166.000 & 481.000 & 0 \\
\hline $\begin{array}{l}\text { Pendiaman }(1 \mathrm{jam}) \\
\text { dalam }\left(\mathrm{sel} / \mathrm{mm}^{3}\right)\end{array}$ & 30 & 278.700 & 160.000 & 480.000 & $2,32 \%$ \\
\hline
\end{tabular}

Berdasarkan tabel hasil uji deskriptif di atas dapat diketahui dari 30 sampel darah EDTA tanpa pendiaman (0 jam) didapatkan rata-rata jumlah trombosit adalah $285.333 \mathrm{sel} / \mathrm{mm}^{3}$ dengan nilai terendah $166.000 \mathrm{sel} / \mathrm{mm}^{3}$ dan nilai tertinggi $481.000 \mathrm{sel} / \mathrm{mm}^{3}$. Dari 30 sampel darah EDTA yang didiamkan selama 1 jam didapatkan rata-rata jumlah trombosit adalah
$278.700 \mathrm{sel} / \mathrm{mm}^{3}$ dengan nilai terendah $160.000 \mathrm{sel} / \mathrm{mm}^{3}$ dan nilai tertinggi 480.000 $\mathrm{sel} / \mathrm{mm}^{3}$, kemudian jika dibandingkan dengan tanpa pendiaman ( 0 jam) dihasilkan penurunan jumlah trombosit sebesar $2,32 \%$. Dari nilai rata -rata jumlah trombosit, maka dapat ditunjukkan dengan grafik (gambar.5) untuk melihat perbedaannya.

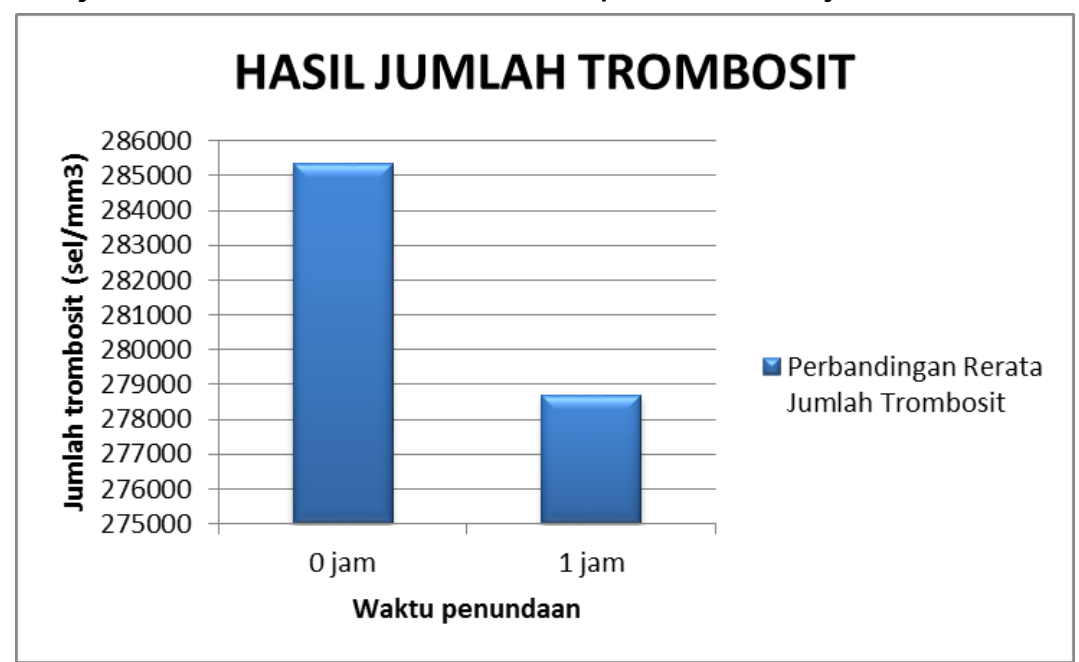

Gambar 6: Grafik Perbedaan Rerata Jumlah Trombosit pada Darah EDTA Tanpa Penundaan (0 jam) dan Darah EDTA Dengan Penundaan 1 jam 
Gambar grafik di atas menunjukkan bahwa rata-rata jumlah trombosit pada sampel darah EDTA tanpa penundaan (0 jam) lebih tinggi dibandingkan pada sampel darah EDTA dengan penundaan selama 1 jam.

\section{Analisis Statistik}

Data yang sudah dianalisis secara deskriptif kemudian dilakukan uji statistik. Uji statistik diawali dengan uji normalitas data untuk mengetahui data penelitian tersebut berdistribusi normal atau tidak dengan menggunakan uji One-Sample Kolmogorov Smirnov test. Syarat uji normalitas data adalah apabila nilai signifikan $<0,05$ maka data tersebut tidak normal (H0 ditolak) dan apabila nilai signifikan $>0,05$ maka data tersebut normal (H0 diterima).

Berdasarkan perhitungan statistik untuk uji normalitas data didapatkan nilai signifikan untuk kelompok data sampel EDTA tanpa penundaan (0 jam) adalah 0,696 dan nilai signifikan untuk kelompok data sampel EDTA dengan penundaan 1 jam adalah 0,832. Kedua kelompok data menunjukan nilai signifikan $>0,05$ sehingga dapat disimpulkan bahwa kedua kelompok data tersebut berdistribusi normal dan data dapat dianalisa menggunakan statistik parametrik.

Uji statistik parametrik yang dapat menunjukan ada tidaknya perbedaan hasil jumlah trombosit pada sampel darah EDTA tanpa penundaan dan sampel darah EDTA dengan penundaan selama 1 jam adalah uji beda untuk sampel yang tidak saling berhubungan (Paired Sample t-Test) dengan taraf signifikan $5 \%$. Syarat uji Paired Sample $t$ Test adalah apabila nilai signifikan $<0,05$ maka ada perbedaan ( $\mathrm{H} 0$ ditolak) dan apabila nilai signifikan $>0,05$ maka tidak ada perbedaan (HO diterima).

Hasil uji beda dengan Paired Sample tTest diperoleh nilai $\mathrm{t}$ hitung pada varians homogeny sebesar 6,896 dengan nilai signifikan 0,000 . Berdasarkan perhitungan statistik nilai signifikan tersebut $<0,05$, maka $\mathrm{HO}$ ditolak atau $\mathrm{Ha}$ diterima, sehingga kesimpulan dari hasil uji statistik ini adalah ada perbedaan hasil jumlah trombosit pada sampel darah EDTA tanpa penundaan (0 jam) dengan sampel darah EDTA dengan penundaan 1 jam.
Fakta yang didapat dari penelitian ini adalah rata-rata jumlah trombosit pada sampel darah EDTA tanpa pendiaman (0 jam) lebih tinggi dari pada sampel darah EDTA yang didiamkan selama 1 jam. Pada sampel darah EDTA tanpa pendiaman (0 jam) didapatkan rata-rata jumlah trombosit adalah 285.333 sel/ $\mathrm{mm}^{3}$ sedangkan sampel darah EDTA yang didiamkan selama 1 jam didapatkan rata-rata jumlah trombosit adalah $278.700 \mathrm{sel} / \mathrm{mm}^{3}$, kemudian jika dihitung persentase penurunannya maka dihasilkan penurunan jumlah trombosit sebesar 2,32\%. Hal ini dikarenakan pada dasarnya darah dengan antikoagulan apabila tidak segera diperiksa akan menyebabkan perubahan morfologi pada sel darah. Trombosit akan terus aktif melakukan metabolisme jika disimpan pada suhu ruang. Hasil metabolisme tersebut adalah akumulasi laktat dan penurunan $\mathrm{pH}$. Trombosit yang memiliki $\mathrm{pH}$ dibawah 6,0 -6,2 akan menyebabkan ketahan trombosit menurun. Selain itu akan mengakibatkan sel trombosit mengalami perbesaran dan disintegrasi.Pengaruh lama pendiaman dapat menyebabkan trombosit akan mengumpul dan membengkak kemudian membentuk fragmen dengan ukuran yang lebih kecil dari trombosit sehingga tidak terhitung sebagai trombosit.

\section{KESIMPULAN}

Ada perbedaan jumlah trombosit darah EDTA yang segera diperiksa dan penundaan selama 1 jam. Jumlah minimal hitung trombosit pada darah EDTA yang segera diperiksa setelah pengambilan sampel (0 jam) adalah $166.000 \mathrm{sel} / \mathrm{mm}^{3}$ dan maksimal adalah $481.000 \mathrm{sel} / \mathrm{mm}^{3}$. Jumlah minimal hitung trombosit pada darah EDTA setelah waktu penundaan selama 1 jam adalah $160.000 \mathrm{sel} /$ $\mathrm{mm}^{3}$ dan maksimal adalah $480.000 \mathrm{sel} / \mathrm{mm}^{3}$. Selisih rerata hitung jumlah trombosit darah EDTA yang segera diperiksa dan setelah waktu penundaan selama 1 jam adalah $2,32 \%$

\section{SARAN}

Penelitian ini berlaku untuk hasil pemeriksaan pada jumlah trombosit yang normal, sehingga untuk kasus kelainan jumlah trombosit seperti trombositopenia perlu penelitian lebih lanjut. 


\section{DAFTAR PUSTAKA}

Aulia, D. (1992), Pemeriksaan Penyaring pada Kelainan Hemostasis, dalam : Setyabudy, R (Ed). (1992). Hemostasis dan Trombosit. Yogyakarta : Balai Penerbit FKUI.

Sacher R. A. Dan Richard A. McPherson, alih bahasa : Brahm U.Pendit dan Dewi Wulandari, editor : Huriawati Hartanto. (2004). Tinjauan Klinis Hasil Pemeriksaan Laboratorium, edisi 11. Jakarta : EGC.

Sukorini, U. Nugroho,D, K. Rizki,M. Hendriawan, B.P.J (2010). Pemantapan
Mutu Internal Laboratorium Klinik. Yogyakarta: Alfa Media.

Yamin, G, dkk. (2004). Pedoman Praktek Laboratorium yang Benar (Good Laboratory Practice). Jakarta : Direktorat Laboratorium Kesehatan Departemen Kesehatan RI.

Widmann F,K, (1992). Tinjauan Klinis Atas Hasil Pemeriksaan Laboratorium, edisi 9. Jakarta :EGC.

Widjajanto. (2004). Regulasi Koagulasi dan Fibrinolisis, dalam : Sutaryo (ed).2004. Tata Laksana Syok dan Perdarahan Pada $D B D$. Yogyakarta : Medika FK-UGM. 